JURNAL KETAHANAN NASIONAL

Vol. 25, No. 2, Agustus 2019, Hal 131-150

DOI:http://dx.doi.org/ 10.22146/jkn.47766

ISSN:0853-9340(Print), ISSN:2527-9688(Online)

Online sejak 28 Desember 2015 di :http://jurnal.ugm.ac.id/JKN

VOLUME $25 \quad$ No. 2, Agustus $2019 \quad$ Halaman 131-150

\title{
Dampak Implementasi Asas Cabotage dan Program Tol Laut Terhadap Ketahanan Wilayah (Studi Di Kabupaten Kepulauan Anambas, Provinsi Kepulauan Riau)
}

\author{
Anwar Sahid \\ Koarmada I/ TNI AL \\ Email: anwarshd47@gmail.com \\ Edy Suandi Hamid \\ Fakultas Ekonomi Universitas Islam Indonesia Yogyakarta \\ Email: edysuandi@yahoo.com \\ Armaidy Armawi \\ Program Studi Ketahanan Nasional, \\ Sekolah Pascasarjana Universitas Gadjah Mada Yogyakarta \\ Email: armaidy@ugm.ac.id
}

\begin{abstract}
S
This study aimed to determined the implementation, constraints and assesed the impact of the cabotage principle and sea toll program on regional resilience in Anambas until the beginning of 2019. Archipelagic districts that had 238 islands in the border region needed ships to supported the development of other sectors and connectivity of disadvantaged, remote, outermost, and border areas (3TP).

This study used qualitative descriptive methods in the form of maps, tables and graphs. Data was obtained through observation, in-depth interviews and documentation in Tarempa, Matak Base, sea toll vessels and the Directorate of Sea Traffic and Freight, including literature studies and internet data.

The result of this studi showed that cabotage principle succeeded in increasing the number of national commercial fleets fivefold since 2005-2018. The upstream oil and gas company at Anambas complied with cabotage and was not subject to operational disruption. The existence of national ships in Indonesian waters contributed to the aspect of defense security as a source of information. The implementation of the sea toll route to Anambas until the fourth year had not succeeded in reducing the price of goods but maintaining the stock of logistics, especially during extreme weather, supporting food security. Cabotage was important for economies and defense security meanwhile sea tolls contributed to inter-regional connectivity to supported the development of remote, frontier, disadvantaged and borderareas (3TP). Both were encouraging national sea freight to dominated the domestic market share.
\end{abstract}

Keyword: Cabotage, Sea Toll, Anambas, Regional Resilience.

\begin{abstract}
ABSTRAK
Penelitian ini bertujuan untuk mengetahui implementasi, kendala dan mengkaji dampak implementasi asas cabotage dan program tol laut terhadap ketahanan wilayah di Anambas hingga awal tahun 2019. Kabupaten kepulauan yang memiliki 238 pulau di wilayah perbatasan membutuhkankapal untuk menunjang pembangunan sektor lain dan konektivitas daerah tertinggal, terpencil, terluar, dan perbatasan (3TP).
\end{abstract}


Metode yang digunakan adalah deskriptif kualitatif dalam bentuk peta, tabel dan grafik. Data diperoleh melalui observasi, wawancara mendalam dan dokumentasi di Tarempa, Matak Base, kapal tol laut dan Direktorat Lalu Lintas Angkutan Laut dilengkapi studi pustaka dan data internet.

Hasil penelitian menunjukkan implementasi asas cabotage berhasil meningkatkan jumlah armada niaga nasional 356 persen pada tahun 2005-2018. Perusahaan hulu migas di Anambas mematuhi cabotage dan tidak terganggu operasionalnya. Keberadaan kapal nasional di perairan Indonesia mendukung aspek pertahanan dan keamanan sebagai salah satu sumber informasi. Implementasi tol laut trayek Anambas hingga awal tahun 2019 belum berhasil menurunkan harga barang tetapi menjaga stok logistik terutama saat cuaca ekstrim, mendukung ketahanan pangan. Cabotage penting bagi perkonomian dan pertahanan keamanan di laut sedangkan tol laut berkontribusi pada konektivitas antarwilayah mendukung pembangunan daerah 3TP. Keduanya mendorong kapal nasional mendominasi angkutan laut dalam negeri.

\section{Kata Kunci: Cabotage, Tol Laut, Anambas, Ketahanan Wilayah}

\section{PENGANTAR}

Pentingnya transportasi laut menjadi keniscayaan dalam mengembangkan pembangunan berbasis kemaritiman. Moda ini berkontribusi sekitar 75 persen pada angkutan barang melalui pelabuhan-pelabuhan yang tersebar di seluruh Indonesia. Sumber daya dari satu daerah lain pulau akan mudah diakses oleh produsen, pemasaran hasil produksi menjadi lebih mudah mencapai pasar yang membutuhkan. Transportasi laut menjadi penunjang bagi sektor pembangunan sektor lain sekaligus menjadi pembuka jalan bagi daerah-daerah terisolasi dalam hal ini pulau-pulau tertinggal, terpencil, terluar, dan perbatasan (3TP). Ketimpangan distribusi penduduk dan sumber daya di Indonesia menjadi faktor penyebab pentingnya mobilitas melalui transportasi laut (Dick, 1989:1).

Asas penyelenggaraan angkutan laut dalam negeri yang memprioritaskan penggunaan kapal berbendera Indonesia, milik WNI atau badan hukum Indonesia dan diawaki oleh WNI yang disertai pembatasan penggunaan angkutan laut asing di wilayah Perairan Indonesia dikenal sebagai asas cabotage. Menurut Hamid (2004:31) asas cabotage memiliki pengertian bahwa muatan angkutan laut dalam negeri harus menggunakan jasa angkutan kapal-kapal nasional milik perusahaan pelayaran nasional, sedangkan menurut istilah katacabotage merupakan istilah kelautan berasal dari Spanyol yaitu caboyang berarti cape(tanjung), pelayaran dari tanjung ke tanjung dalam satu pantai yang kemudian berkembang menjadi dari tanjung ke tanjung pada pulau yang berbeda dalam satu negara (Martonodan Tjahjono, 2011:16).

Hal yang mendorong negara-negara di dunia menerapkan cabotagebervariasi, mulai dari perlindungan industri dalam negeri hingga perlindungan garis pantai suatu negara dari ancaman militer atau teroris sebagaimana disampaikan oleh Fendos dkk (2016:716), di samping itu kebijakan asas cabotage yang membatasi kebebasan pergerakan kapal asing dalam transportasi laut domestik suatu negara bukanlah hal baru. Fendos, dkk (2016) mengambarkan Jepang contoh yang baik dari sebuah negara dengan kebijakan yang digunakan untuk tujuan perlindungan Industri, sementara bagi Amerika Serikat kebijakan ini digunakan untuk alasan kedaulatan dan keamanan.

Indriyani (2012:135) menjelaskan tentang pentingnya menerapkan asas cabotage bagi Indonesia dikaitkan dengan kondisi geografi namun demikian perlu konsistensi dalam pelaksanaannya. Di sisi lain pihak industri jasa angkutan laut tentu 
saja menginginkan keuntungannya meningkat, para pengguna jasa menginginkan biaya terjangkau dengan beberapa alternatif pilihan sedangkan pemerintah menginginkan jaminan ketersediaan pelayaran pada saat dibutuhkan, hal ini sesuai dengan yang dikemukakan oleh Purwaka (1993:3).

Instruksi Presiden Nomor 5 tahun 2005 tentang Pemberdayaan Industri Pelayaran Nasional menekankan agar asas cabotagedijalankan secara konsekuen dengan melibatkan pihak-pihak yang memiliki kewenangan. Lahirnya Undang-Undang Nomor 17 Tahun 2008 tentang Pelayaran kembali menegaskan komitmen negara dalam penerapan asas cabotage, yang tercermin dalam Pasal 8 bahwa kegiatan angkutan laut di dalam negeri dilakukan oleh perusahaan angkutan laut nasional, dengan kapal berbendera Indonesia serta diawaki oleh awak berkewarganegaraan Indonesia. Aparat penegak hukum di laut memiliki keterbatasan dalam melaksanakan pengawasan seluruh perairan Indonesia setiap saat sehingga perlu melibatkan komponen negara di laut yang meliputi armada pemerintah, armada niaga, armada survei dan pemetaan, armada perikanan, industri dan jasa maritim, serta masyarakat maritim lainnya.Keberhasilan penerapan asas cabotage yang ditandai dengan bertambahnya jumlah armada niaga nasional menguasai pasar pelayaran antarpulau di Indonesia berpotensi membantu meningkatkan pengawasan wilayah perairan Indonesia.

Tol laut merupakan sebuah konsep terobosan dalam rangka memanfaatkan potensi wilayah Indonesia melalui elaborasi perencanaan trayek angkutan laut, subsidi angkutan laut, revitalisasi pelayaran rakyat dan pengembangan industri berbasis wilayah. Tol laut sebagai istilah untuk menyederhanakan penyebutan program Presiden Joko Widodo yang berupa pemberian fasilitas subsidi atau public service obligation kepada operasional armada tol laut dengan tujuan kapal dapat tetap berlayar secara teratur meski tanpa muatan balik yang cukup untuk menjamin pelayaran rutin dan terjadwal dari wilayah timur ke wilayah barat Indonesia maupun sebaliknya untuk meminimalisir biaya logistik. Harapannya dengan keteraturan jadwal kapal pada pelabuhan yang ditentukan akan menstimulus pertumbuhan ekonomi di wilayah-wilayah baru di luar Jawa (Prihartono, 2015:2).Penyelenggaraan kewajiban pelayanan public untuk angkutan barang dalam rangka pelaksanaan tol laut tertuang dalam Perpres 71 Tahun 2015 memiliki sasaran untuk menjamin kelangsungan pelayanan penyelenggaraan angkutan laut ke daerah, menjamin ketersediaan barang, mengurangi disparitas harga antarwilayah dan sebagai upaya stimulus perekonomian dan pembangunan di daerah, khususnya wilayah 3TP.

Rumi (2017:113) menggambarkan penerapan asas cabotage di Indonesia berhasil memajukan sektor pengangkutan laut Indonesia yang ditandai meningkatnya jumlah armada kapal nasional dan penguasaan muatan dalam negeri. Sementara itu program tol laut dapat mengatasi permasalahan distribusi logistik nasional, memperlancar konektivitas Indonesia dan dapat mendukung salah satu tujuan dari asas cabotage dalam memperlancar arus perpindahan orang dan/atau barang melalui perairan dengan mengutamakan dan melindungi angkutan di perairan dalam rangka memperlancar kegiatan perekonomian nasional.

Soemarwoto (2014:38) menyatakan bahwa dampak merupakan munculnya suatu 
perubahan yang terjadi akibat dari suatu aktivitas, baik yang bersifat alamiah maupun aktivitas yang dilakukan oleh manusia, dengan membandingkan antara keadaan sebelum dan sesudah.Penilaian dilakukan terhadap perubahan yang terjadi berkaitan dengan transportasi laut dan aspek ketahanan wilayah Kabupaten Kepulauan Anambas dalam periode waktu tertentu untuk memperoleh gambaran dampak implementasi asas cabotage dan program tol laut.Implementasi kebijakan pada dasarnya merupakan cara dan upaya agar sebuah kebijakan mencapai tujuan yang diinginkan.

Sunardi (1997:55) menjelaskan bahwa pemerataan pembangunan ke suatu wilayah dengan Pulau Jawa sebagai center of grafity ditentukan oleh faktor-faktor: intensitas dan kualitas komunikasi; intensitas dan kualitas transportasi; serta pengamanan hubungan komunikasi dan transportasi dalam segala situasi.Ketiga faktor tersebut berfungsi sebagai penyalur materi dan material pembangunan,wahana kepanjangan kekuasaan dan administrasi pemerintahan, dan sebagai wahana pembinaan persatuan dan kesatuan. Artinya komunikasi, transportasi dan pengamanannya menjadi prasyarat terlaksananya pembangunan wilayah. Hal ini sejalan dengan upaya pemerintah saat ini yang mengupayakan agar wilayah $3 \mathrm{TP}$ secara rutin dan terjadwal dilalui oleh trayek angkutan laut bersubsidi (tol laut) sehingga konsep trade follows the ships menjadi realita pada masa depantermasuk di wilayah Anambas.

Implementasi asas cabotage dan program tol laut dapat mendorong berkembangnya industri pelayaran dalam negeri sekaligus menjadi terobosan pemerintah dalam rangka menstimulus para investor bidang ini agar ambil bagian melayari trayek-trayek hingga ke wilayah 3TP. Kehadiran armada niaga nasional di laut yurisdiksi Indonesia dalam rangka implementasi kebijakan ini mampu memberikan andil dalam kerangka peningkatan kekuatan laut (sea power). Hal ini mengingat kemampuan aparat keamanan laut belum sepenuhnya mampu mencakup seluruh yurisdiksi Indonesia dalam waktu yang bersamaan. Kapal-kapal niaga nasional dapat berperan menjadi perpanjangan mata dan telinga aparat di laut. Konsepsi geopolitik Sir Walter Raleigh menyatakan bahwa siapa yang menguasai laut akan menguasai perdagangan, siapa yang menguasai perdagangan akan menguasai kekayaan dunia dan sea power tidak cukup hanya mengandalkan kapal TNI Angkatan Laut melainkanseluruh aspek non militer penggunaan laut (Iliopolus, 2009). Sejalan dengan hal itu Till dalam (Esterhuyse, 2018) menyatakan bahwa armada kapal sipil merupakan salah satu unsur-unsur kekuatan (elements) penting dalam penguasaan laut selain pangkalan/pelabuhan dan instrumen pertempuran.

Studi ketahanan wilayah relevan dilakukan di wilayah Anambas karena penelitian yang sejenis belum pernah dilakukan. Kedua kebijakan terkait kelautan ini telah diimplementasikan namun belum pernah dilakukan kajian mendalam dilihat dari aspek ketahanan wilayah. Selain itu wilayah Anambas masuk kategori daerah 3TP yangberada di Laut Cina Selatan. Salah satu kawasan yangsaat ini sedang menjadi sorotan dunia.

Metode penelitian yang digunakan dalam penelitian ini adalah deskriptif kualitatif melalui pengamatan langsung atau observasi, wawancara mendalam dan dokumentasi. Pengambilan data dilakukan di Tarempa, Palmatak dan Jakarta. Peneliti 
Anwar Sahid, Edy Suandi Hamid, Armaidy Armawi -- Dampak Implementasi Asas Cabotage dan Program Tol Laut Terhadap Ketahanan Wilayah (Studi Di Kabupaten Kepulauan Anambas, Provinsi Kepulauan Riau)

mewawancarai Direktur Lalu Lintas dan Angkutan Laut, Pejabat Pemda, tokoh masyarakat dan pengusaha Anambas dan karyawan perusahaan hulu migas. Observasi, wawancara dan dokumentasi dilakukan di Tarempadan Palmatakmeliputi PT. Medco Energi Internasional Tbk, Jetty Matak, kapal tol laut dan pelabuhan Tarempa.

\section{PEMBAHASAN}

\section{Kabupaten Kepulauan Anambas}

Anambas merupakan sebuah kabupaten kepulauan yang terletak di wilayah perairan perbatasan Indonesia, berhadapan langsung dengan Laut China Selatan atau oleh Indonesia mulai tahun 2017 dinamakan Laut Natuna Utara.Daerah pemekaran dari Kabupaten Natuna sebagai induknya ditetapkan berdasarkan UU No. 33 Tahun 2008.

Wilayah Anambas terlihat dalam gambar 1 berbatasan dengan perairan Laut Cina Selatan pada Zona Ekonomi Eksklusif
Vietnam di sebelah utara, di sisi barat bersinggungan dengan Perairan Malaysia, di sisi selatan berbatasan dengan wilayah laut Kepulauan Tambelan,Bintan dan timur berdampingan dengan wilayah laut Kabupaten Natuna. Seluruhnya perbatasan laut, tidak ada batas darat dengan kabupaten/kota lain. Wilayahnya berupa gugusan pulau-pulau kecil yang berjumlah 238 buah sebagian belum berpenghuni memiliki luas wilayah daratan kurang lebih $590,14 \mathrm{~km}^{2}(1,27 \%)$ dan luas lautan $46.033,81 \mathrm{Km}^{2}$.

Jarak tempuh lewat laut menuju Kota Tarempa, pusat ekonomi dan pemerintahan Anambas, kurang lebih 600 mil laut dari Jakarta, 195 mil laut dari Tanjung Pinang/ Batam dan 300 mil laut dari Pontianak. Lima dari tujuh wilayah kecamatan di kabupaten ini dihubungkan dengan jalur laut.Kondisi ini menyebabkan Anambas sangat bergantung pada angkutan laut dalam melaksanakan pembangunan, transportasi laut menjadi

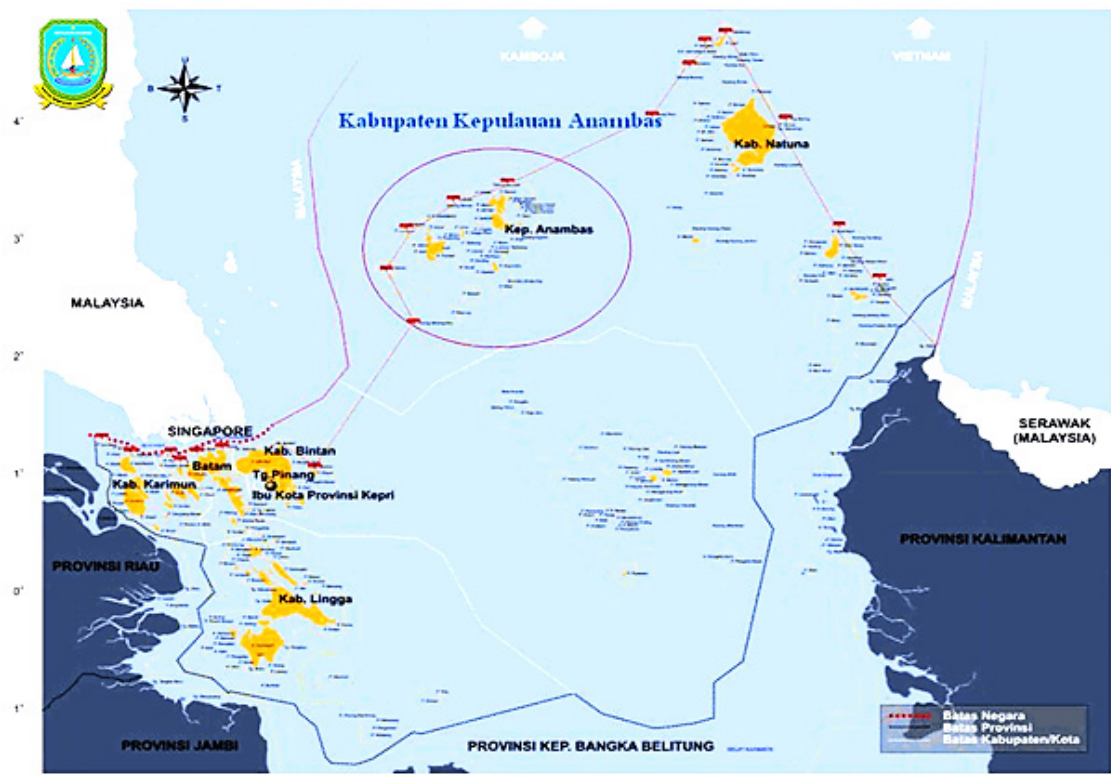

Sumber: http://pidii.info/images/investasi/4th-editions/kab-kepulauan-anambas/PetaAnambas.gif diakses 24 April 2019: 16.30 WIB 
pilihan utama masyarakat dalam mobilitasnya.

Matak Base yang berlokasi di Kecamatan Palmatak seperti telihat pada gambar 2 berada di sisi utara Anambas merupakan pangkalan terdepan tiga perusahaan hulu minyak dan gas bumi. Pangkalan iniberfungsi mendukung operasional pengeboran lepas pantai (offshorerig) blok Natuna dilengkapi fasilitas dermaga pelabuhan laut, bandar udara khusus dan perkantoran yang dilengkapi asrama. Aktivitas kapal-kapalyang beroperasi untuk perusahaan tersebut dimonitor oleh otoritas Matak Port dan pihak syahbandar Tarempa. Implementasi asas cabotagedi wilayah Anambas tercermin dari persentase jumlah kapal nasional dan kapal asing yang beroperasi untuk perusahaan-perusahaan tersebut.

Gambar 2 menggambarkan wilayah Anambas yang terdiri dari 7 kecamatan dimana antar wilayahnya dihubungkan oleh laut, sehingga transportasi laut merupakan prasyarat bagi kelangsungan pembangunan di wilayah ini. Meskipun wilayah didominasi laut dari tahun ke tahun indeks pembangunan manusia Anambas meningkat sebagaimana ditunjukkan oleh tabel 1, demikian halnya dengan besaran dana bagi hasil (DBH) Migas seperti tercantum dalam tabel 2.

Tabel 1

Data Penduduk

\begin{tabular}{|l|l|l|l|}
\hline Penduduk & \multicolumn{1}{|c|}{2015} & \multicolumn{1}{|c}{2016} & \multicolumn{1}{|c|}{2017} \\
\hline Miskin & $6,58 \%$ & $6,73 \%$ & $6,87 \%$ \\
\hline IPM & 65,86 & 66,30 & 67,06 \\
\hline Jumlah & 40414 & 40921 & 41412 \\
\hline
\end{tabular}

Sumber: BPS Kabupaten Kepulauan Anambas 2018

Tabel 2

Dana Bagi Hasil Minyak dan Gas Bumi untuk

Anambas

\begin{tabular}{|c|c|c|c|c|}
\hline DBH & $\mathbf{2 0 1 6}$ & $\mathbf{2 0 1 7}$ & $\mathbf{2 0 1 8}$ & $\mathbf{2 0 1 9}$ \\
\hline Rp Miliar & 28 & 56 & 134 & 256,5 \\
\hline
\end{tabular}

Sumber:https://batamtoday.com/anambas/ read/120916/DBH-Migas-Dongkrak-KenaikanAPBD-Anambas-2019 diakses 25 Februari 2019 (09.00)

\section{Implemantasi Asas CabotageDan Program Tol Laut Di Wilayah Anambas}

Secara umum antara asas cabotage dan tol laut memiliki kesamaan arah yaitu,

Gambar 2

Wilayah Kabupaten Kepulauan Anambas

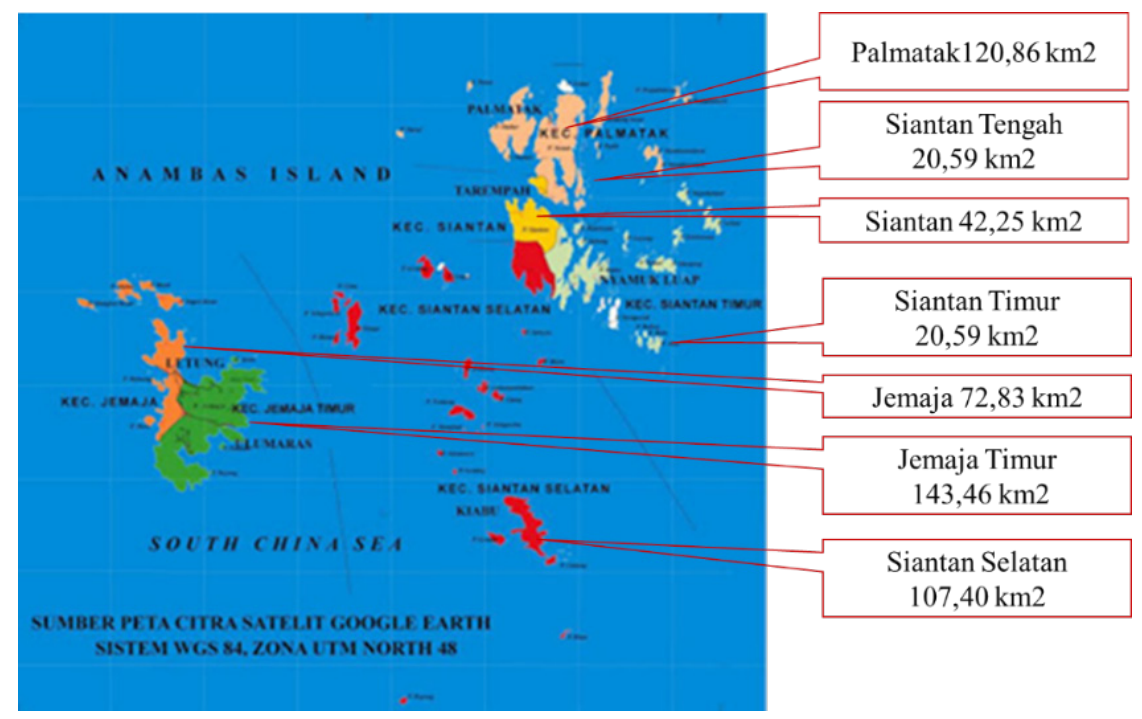

Sumber: Diolah dari Google Earth dan BPSKabupaten Kepulauan Anambas, 2018 
pertama, kehadiran kapal berbendera Indonesia di wilayah perairan Indonesia akan memberikan kebanggaan (pride) bagi rakyat Indonesia; kedua, dominasi kapal nasional pada pasar angkutan laut dalam negeri (prinsip cabotage) secara langsung atau tidak langsung mengatasi persoalan logistic cost dan disparitas harga antardaerah yang saat ini diupayakan pemerintah (tol laut); ketiga, menjamin ketersediaan angkutan laut secara rutin dan terjadwal ke seluruh wilayah NKRI.

Asas cabotage diimplementasikan oleh pemerintah dalam rangka mendorong kapal nasional mendominasi pasar domestik dan mencegah armada kapal asing masuk terlalu jauh dalam pasar angkutan laut dalam negeri. Hal ini mengingat pasar ekspor impor Indonesia sudah didominasi oleh kapal asing, jika pemerintah melepaskan pertahanan terakhir ini maka pasar domestik pun akan sangat mungkin didominasi kapal asing. Di sisi laintol laut lahir didorong oleh permasalahan logistic cost di negeri ini yang menyebabkan harga barang kebutuhan pokok antara wilayah produksi dan konsumsi memiliki disparitas tinggi.

Pemerintah melalui Kementerian Perhubungan masih memberikan ruang pada penggunaan kapal asing dalam beberapa bidang industri termasuk hulu minyak dan gas bumi dengan ketentuan dan persyaratan tertentu. Kapal-kapal nasional belum cukup mampu mendukung seluruh pekerjaan perusahaan hulu migas lepas pantai sehingga perlu mengakomodir kepentingan pemilik pekerjaan dalam memperoleh kapalkapal yang dibutuhkan, namun dengan tetap mengimplementasikan asas cabotage secara bertahap dan konsisten. Hal ini dilakukan melalui pengetatan syarat-syarat ijin penggunaan kapal asing pada sektor-sektor yang selama ini belum mampu didukung industri pelayaran nasional.

Pengetatan syarat dilakukan dengan Peraturan Menteri Perhubungan Nomor 92 Tahun 2018 tertanggal 20 September 2018 tentang Tata Cara Dan Persyaratan Pemberian Persetujuan Penggunaan Kapal Asing Untuk Kegiatan Lain Yang tidakTermasuk Kegiatan Mengangkut Penumpang dan/atau Barang Dalam Kegiatan Angkutan Laut Dalam Negeri. Hal ini sejalan dengan komitmen penggunaan produk dalam negeri (TKDN) pada kegiatan hulu migas sesuai Permen ESDM No.15 Tahun 2013 yang menargetkan pada tahun 2017-2020jasa pemboran di laut sebesar 45 persen dan jasa perkapalan 80 persen, jangka panjang tahun 2021-2025 ditargetkan 55 persen jasa pemboran di laut dan 85 persen jasa perkapalan menggunakan komponen dalam negeri.

Direktur Lalulintas dan Angkutan Laut Kemenhub, Wisnu Handoko menyampaikan mekanisme sebelum pihak industri pelayaran mengajukan ijin penggunaan kapal asing untuk keperluan pekerjaan hulu migas di offshore. Perusahaan yang membutuhkan kapal dengan spesifikasi tertentu pertama wajib mengumumkan secara terbuka melalui media massa dan berkonsultasi dengan Indonesian Ships Owner Association (INSA) dan jika kapal nasional tidak tersedia atau belum cukup tersedia yang memenuhi spesifikasi yang dibutuhkan baru diberikan kesempatan mengajukan ijin kepada Kementerian Perhubungan untuk sewa kapal asing sesuai standar yang dibutuhkan. Hal ini sebagai upaya pemerintah menjembatani ketentuan cabotage sesuai dengan Undang-undang Pelayaran dan keberlangsungan industri tertentu yang membutuhkan kapal asing dalam operasionalnya.Kondisi ini sejalan dengan 
logika ketahanan nasional dalam pengelolaan sumber daya alam menurut Wahyuhono (2019) bahwa keberhasilan produksi secara maksimal akan dapat memenuhi kebutuhan energi dan menopang sumber pendapatan nasional. Keberhasilan produksi pada kilang migas lepas pantai (offshore rig) diawali dengan pemilihan kapal-kapal yang sesuai standar dan spesifikasi dalam melakukan pekerjaan eksplorasi dan eksploitasi.

Keberhasilan implementasi asas cabotage ditunjukkan dengan peningkatan jumlah armada niaga nasional tercatat 6041 kapal pada 31 Mei 2005 menjadi 29.928 kapal pada 30 November 2018dengan jumlah perusahaan dari 1591 menjadi 3565 perusahaan. Namun demikian pada pasar angkutan ekspor impormasih didominasi kapal asing yaitu sebesar93,7persen pada tahun 2016, sisanya kapal nasional. Artinya dalam angkutan ekspor impor armada niaga nasional baru sebatas menjadi feeder bagi kapal asing. Defisit jasa transportasimenyumbang USD 9 miliar dalam defisit transaksi berjalan 2018 dan cenderung naik mengingat term of delivery dalam ekspor Indonesia sebagian besar menggunakan ketentuan FOB (free on board) dimana kapal pengangkut barang menjadi tanggung jawab pembeli di luar negeri.

Keadaan tersebut tidak lepas dari tarik ulur kebijakan pemerintah dalam ketentuan angkutan ekspor impor. Sebagai contoh ketentuan penggunaan kapal nasional dalam ekspor CPO, batu bara dan impor beras menurut Permendag 82 Tahun 2017 semestinya diterapkan mulai 1 Mei 2018 namun diubah menurut Permendag 48 Tahun 2018pemberlakuan ditunda hingga 1 Mei 2020. Hal ini atas masukan dan keberatan dari eksportir dan belum siapnya industri pelayaran nasional menyediakan
kapal.Hal serupa terjadi pada tahun 2013 dimana nota kesepahaman rencana aksi pengunaan CIF (cost, insurance, freight) oleh Menteri Perdagangan Gita Wiryawan dengan sejumlah asosiasi pelaku usaha sebagai upaya mendorong penggunaan kapal nasionaldalam kegiatan ekspor namun setahun berikutnya keluar Peraturan Menteri Keuangan No. 41/ PMK.04/2014 melonggarkannya dengan cukup mencantumkan nilai premi asuransi dan freight ke dalam dekumen pemberitahuan ekspor barang dan dalam prakteknya eksportir boleh kembali memilih ketentuan FOB. Pada tahun 2019 hal positif dilakukan pemerintah melalui Peraturan Menteri Keuangan No. 32/ PMK.010/2019 kebijakan pajak pertambahan nilai (PPN) nol persen untuk beberapa kegiatan ekspor jasa kena pajak salah satunya jasa pengurusan trasnportasi (freight forwarding) yang dapat diartikan sebagai upaya memberi kemudahan kepada industri pelayaran nasional lebih berperan dalam angkutan ekspor.

Gambaran penerapan asas cabotage di wilayah Anambas khususnya pada perusahaan bidang hulu minyak dan gas bumi dapat dilihat dari aktivitas kapal-kapal di Jetty Matak yang berada di Pulau Palmatak. Dispensasi penggunaan kapal asing semestinya berakhir pada bulan Desember 2017, namun pada beberapa sektor termasuk industri hulu migas masih diberi kesempatan hingga armada niaga nasional tersedia atau cukup tersedia memenuhi kebutuhan proyek minyak dan gas lepas pantai. Meskipun demikian Permenhub 92 tahun 2018 tetap berusaha mendorong perusahaan pelayaran nasional agar masuk dan diprioritaskan pada sektor hulu migas melalui pengetatan syarat dan ketentuan dalam pengajuan ijin penggunaan kapal asing. Menurut Wisnu Handoko penggunaan kapalasing pada proyek drilling migas akan 
Anwar Sahid, Edy Suandi Hamid, Armaidy Armawi -- Dampak Implementasi Asas Cabotage dan Program Tol Laut Terhadap Ketahanan Wilayah (Studi Di Kabupaten Kepulauan Anambas, Provinsi Kepulauan Riau)

tetap diberikan ijin hingga kapal nasional tersedia:

"sepanjang industri kapal kita tidak mampu membuat kapal seperti itu kemudian perusahaan pelayaran tidak mampu membeli dan mengoperasikan kapal itu selamanya ijin ini akan terus, mau 2017, mau 2020, mau 2025 kalau kapal ini belum tersedia tetap Indonesia akan menggunakan itu (kapal asing)" (Wawancara 25 Februari 2019).

Hasil penelitian lapangan menunjukkan jumlah kapal asing yang beroperasi di offshore rig wilayah Anambas sesuai tabel 3 tercatat pada 2008 berjumlah 406 kapal turun menjadi 299 pada 2010 dan pada tahun 2018 tidak ada kapal asing yang dioperasikan oleh PT. Medco Energi Tbk. Sebaliknya jumlah kapal nasional meningkat. Kapal-kapal yang dipergunakan di offshore wilayah ini antara lain tipe Ancorage Handling Tug and Supply(AHTS), crew boat dan commercial boat untuk operasional sehari-hari. Selain tidak ada proyek drilling pada 2018, operasional offshore rigseharihari mengoptimalkan kapal yang ada dan memprioritaskan kapal nasional sehingga jumlah penggunaan kapal asing berkurang.

Tabel 3

Aktivitas Kapal Di Wilayah Kabupaten Kepulauan Anambas

\begin{tabular}{ccccc}
\hline No & Kapal & $\mathbf{2 0 0 8}$ & $\begin{array}{c}\text { Tahun } \\
\mathbf{2 0 1 0}\end{array}$ & $\mathbf{2 0 1 8}$ \\
\hline 1. & Asing & 406 & 299 & 0 \\
2. & Indonesia & 399 & 272 & 482 \\
\hline \multicolumn{4}{c}{ Sumber: Matak Port Supervisor, 2019 }
\end{tabular}

Kegiatan ekspor minyak dan gas bumi langsung dari lokasi anjungan lepas pantai (offshoreplatform) wilayah Anambas sebagian masih mempergunakan kapal asing jenis supertanker. Tercatat pada tahun 2017 kapal supertanker asing berjumlah 22 dari 42 kapal yang mengangkut hasil produksi migas dan pada tahun 2018 berkurang menjadi 16 dari 45 kapal. Selain itu ekspor ikan hidup juga masih menggunakan kapal asing pengangkut ikan hidupyang melayani rute Anambas Hongkong. Kapal dengan desain khusus tersebut masih diijinkan beroperasi ke wilayah Anambas.Kapal dating dari Hongkong membeli ikan hidup langsung dari nelayan pembudidaya ikan napoleon dan kerapu di Desa Airsena, Kecamatan Siantan Tengah. Kelonggarandalam penerapan cabotage di wilayah ini atas pertimbangan bahwa kapal asing tersebut berkontribusi besar pada perekonomian Anambas maupun nasional.

Implementasi program tol laut secara umum berhasil menjaga ketersediaan angkutan laut yang rutin dan terjadwal ke berbagai daerah, dampak terhadap penurunan harga bervariasi ditentukan oleh kondisi daerah tujuan dan manajemen distribusi setelah muatan tiba di pelabuhan tujuan.Program tol laut dalam implementasnya melibatkan Kementerian Perhubungan sebagai pemberi tugas dan penyedia sarana dan prasarana, Kementerian Perdagangan sebagai pelaksana dan verifikasi muatan serta pemberi surat perintah muat (shippinginstruction), dan PT. Pelayaran Nasional Indonesia sebagai operator, sehingga ketiganya harus terus berkoordinasi dan bekerja sama dengan pemerintah daerah setempat dalam rangka mencapai tujuan program tol laut menurunkan disparitas harga.

Tol laut yang melayani trayek ke Kabupaten Kepulauan Anambas mulai beroperasi menggunakan KM. Caraka Jaya Niaga III-4 sejak 22 Januari 2016 dengan rute Jakarta-Tarempa-Natuna-Jakartamemasuki tahun keempat pada tahun 2019 belum berhasil menurunkan harga-harga barang di pasaran Tarempa, namun diakui masyarakat 
dan pemerintah daerah telah berhasil menjaga ketersediaan stok barang sepanjang tahun. Stok barang kebutuhan masyarakat yang sebelumnya 'putus' ketika memasuki musim cuaca ekstrim tidak terjadi lagi. Meskipun tarif tol laut jauh lebih murahdibandingkan kapal swasta yang telah lebih dahulu melayani trayek Anambas namun harga-harga barang belum turun disebabkanpermasalahan distribusi di Kota Tarempa. Mulai barang turun dari kapal hingga sampai ke tangan konsumen.

Upaya mengatasi kendala tersebut dilakukan dengan evaluasi bersama oleh Dirjen Hubla, Kementerian Perdagangan dan PT. Pelni dengan mendengar masukan dari pemerintah daerah.Kapal tol laut trayek Anambas semula dilayani oleh KM. Caraka Jaya Niaga III-4 tanpa menggunakan kontainer dan kemudian digantikan oleh KM. Logistik Nusantara 4mulai bulan Februari 2019 kondisikapal lebih baru, lebih cepat dan barang wajib dimuat dalam kontainer. Selain dua kapal tersebut,pada tahun 2018 ditambahkan KM. Sabuk Nusantara 80 untuk melayanirute dalam wilayah ProvinsiKepulauan Riautermasuk Tarempa dan Pontianak. Kapal pengangkut barang inidilengkapi akomodasi penumpang dengan sasaran masyarakat ekonomi menengah ke bawah.

Kehadiran tol laut memberikan kepastian jadwal pelayaran angkutan laut khususnya barang, sehingga permasalahan logistik di wilayah 3 TP berangsur-angsur dapat diminimalisir. Masyarakat Anambas antusias menyambut kehadiran tol laut namun beberapa kendala teknis di lapangan menimbulkan keengganan para pengusaha lokal untuk beralih ke kapal tol laut. Prosedur dan tatacara pengiriman barang yang belum dipahami oleh para pengusaha Anambas memerlukan sosialisasi untuk menghilangkan kesan rumit.
Jaringan bisnis dengan pengusaha supplier Jakartaperlu dikenalkan kepada mereka agar terjalin komunikasi dan hubungan bisnis berkelanjutan.Masih ada kekhawatiran barang rusak dan hilang tidak ditangani dengan jelas. Berbeda halnya bagi para pengusaha Tionghoa di Tarempa yang hingga kini lebih dominan memanfaatkan jasa tol laut, selain jaringan bisnisnya sudah kuat selisih biaya angkut tol laut menjadi peluang meraup margin lebih tinggi.

\section{Kendala Dalam Implementasi Asas Cabotage Dan Program Tol Laut}

Implementasi asas cabotage di wilayah Anambas berkaitan erat dengan operasional perusahaan minyak dan gas bumi yang berbasis di Matak. Kendala dihadapkan pada upaya mencapai target produksi migas yang salah satunya ditentukan faktor kapal pendukung proyek drilling di offshore rig,dimana kapal nasional tidak tersedia ataubelum cukup tersedia dengan kemampuan dan reputasi dalam pekerjaan tersebut sesuai spesifikasi dan standar safety internasional yang diinginkan perusahaan. Hal ini menjadi faktor penghambat para pemilik pekerjaan lepas pantai beralih menggunakan kapal nasional, artinya pemerintah harus tetap memberi ruang atau melonggarkan cabotage pada penggunaan kapalasing untuk industri hulu migas lepas pantai agar proyek-proyek terlaksana dengan baik sesuai jadwal dan memenuhi target produksi yang telah ditentukan.Pemerintah tidak mungkin merusak iklim investasi pada industri hulu migas dengan asas cabotage yang dinilai masih dapat ditolerir untuk ditunda. Dilema antara kelangsungan proyek pengeboran dan penerapan cabotage akan terus muncul hingga industri pelayaran nasional tergerak masuk dan mampu bersaing 
Anwar Sahid, Edy Suandi Hamid, Armaidy Armawi -- Dampak Implementasi Asas Cabotage dan Program Tol Laut Terhadap Ketahanan Wilayah (Studi Di Kabupaten Kepulauan Anambas, Provinsi Kepulauan Riau)

dengan kapalasing pada sektor ini sehingga pemilik pekerjaan offshore memiliki opsi kapal nasional untuk dipilih.

Keengganan industri pelayaran nasional untuk melakukan pengadaan/pembuatan kapal pendukung industri hulu migas disebabkan pertimbangan bisnis dimana biaya sewa kapal asing dinilai lebih rasional. Di samping itu kebijakan pemerintah hingga saat ini masihmemberi ruang penggunaan kapal asing pada sektor ini. Selain itu pemerintah daerahbelum berperan aktif dalam pengawasan penerapan cabotage di wilayahnya.Di sisi lain industri pelayaran nasionaltelah merasa cukup dan nyaman dengan pasar angkutan domestik yang terlindungi oleh penerapan cabotage oleh pemerintah.Hal ini dapat semakin menjauhkan kapal-kapal nasional dari pemenuhan standar internasional baik spesisifikasi maupun safety yang dibutuhkan industri hulu migas maupunpelabuhan-pelabuhan negaratujuan ekspor yang akan disandari. Hal inimenjadi salah satu jawaban mengapa angkutan eskpor impor Indonesia masih didominasi oleh kapal asing.

Upaya dalam mengatasi kendala yang dihadapi pada implementasi asas cabotage di antaranya melalui penerbitan Permenhub RI Nomor PM 92 Tahun 2018 tentang syarat dan ketentuan yang harus dipenuhi oleh perusahaan pengguna kapal asing untuk mendapatkan persetujuan penggunaan kapal asing. Hal ini dalam rangka memberi peluang kepada kapal-kapal berbendera Indonesia untuk dipilih terlebih dahulu sebelum perusahaan tersebut menggunakan kapal asing. Selain itu pemerintah akan lebih mempriotitaskan kapal berbendera asing yang berkomitmen akan melakukan pergantian menjadi berbendera Indonesia sebelum beroperasi di Indonesia dan kapal berbendera asing yang dalam proses pembelian oleh WNI atau Badan Hukum Indonesia yang dibiayai oleh leasing. Upaya menggugah kesadaran tentang pentingnya asas cabotage perlu dilakukan melalui sosialisasi kepada pemerintah daerah maupun masyarakat di wilayah operasi kapal tersebut agar dapat ikut berperan dalam pengawasan.Kapalkapal asing yang beroperasi untuk sektor tertentu sesuai Permenhub tersebut diberikan kesempatan sampai dengan Desember 2020 dan setelahnya akan dilakukan evaluasi kembali apakah dilanjutkan atau dihentikan sama sekali.

Sementara itu kelangsungan program tol laut secara umum masih sangat bergantung pada subsidi pemerintah hingga kondisi balance of trade tercapaiatau produksi dan konsumsi daerah meningkat seiring dengan konektivitas yang dihadirkan oleh tol laut. Kegigihan dan konsistensi pemerintah akan diuji terutama berkaitan perubahan kebijakan yang sering dilakukan pada momen pergantian pimpinan nasional. Keberhasilan implementasi kebijakan dalam transportasi laut dalam rangka menstimulus pembangunan daerah 3TP akan terwujud jika dilakukan dalam jangka menengah atau panjang karena segala sesuatunya memerlukan proses.

Kendala yang dihadapi program tol laut rute Anambas antara lain kapasitas produksi dan konsumsi daerah tidak sesuai dengan kapasitas muat kapal, kapal besar muatan sedikit. KM. Caraka 34 yang pada awalnyabelum menggunakan kontainer menimbulkan risikobarangrusak atau hilang dimana hal itu belum tertangani dengan jelassiapa yang bertanggung jawab karena muatan tidak diasuransikan. Situasi ini menimbulkan keengganan masyarakat Anambas dan pelaku usaha menggunakan jasa tol laut, sehingga selama tiga tahun 
berjalan pengguna jasa tol laut di Tarempa baru mencapai rerata 7 pengusaha atau pengirim barang dalam setiap trip pelayaran dari Jakarta ke Tarempa dengan kapasitas total muatan dalam satu tahun mencapai 2885 ton. Kondisi ini sangat kontras dengan kapasitas muat satu kali pelayaran kapal tol laut yang mampu mengangkut muatan hingga 2400 ton tergantung jenis muatan. Artinya load factor tol laut trayek Tarempa baru mencapai sekitar 16 persen dalam setiap trip pelayaran. Muatan balik dari Tarempa ke Jakarta tercatat selama tahun 2018 dalam 13 trip pelayaran baru mencapai 111ton dengan total pengirim barang 21 orang atau pengusaha.

Kendala berikutnya adalah padatnya lalu lintas keluar masuk kapal di pelabuhan Tarempa baik kapal penumpang maupun kapal barang yang mengandalkan satu dermaga sepanjang 135 meter dengan alur masuk pelabuhan sempit dikelilingi pemukiman penduduk. Keadaan ini turut memicuketerlambatan jadwal kapal tol lautdan proses bongkar muat barang. Ketiadaan gudang, pola kerja buruh bongkar muat dan kondisi jalandi Kota Tarempa ikut berkontribusi terhadap permasalahan distribusi barang.Proses pendistribusian barang setelah turun dari kapal tol lauthingga ke tangan konsumen menjadi salah satu penyebab harga barang-barang di Tarempa belum turun. Selain itu para pengusaha Tarempa lebih dominan mempengaruhi harga barang di pasaran.

Upaya mengatasi kendala yang dihadapi dalam implementasi tol laut antara lain mengganti KM. Caraka Jaya NiagaIII-4 dengan KM. Logistik Nusantara 4 yang lebih kecil, lebih baru dan kemampuan mesin lebih baik, dilengkapi bowthrusteryang mempermudah proses sandar dan kewajiban seluruh barang dimuat dalam kontainer. Hal ini dalam rangka mengantisipasi kehilangan dan kerusakan barang yang terjadi sebelumnya, dimana terhadap kejadian tersebut pemerintah daerah dan pihak kapal selama ini belum memberikan solusi,baru sebatas membuatkan berita acara dan melaporkannya ke pusat sebagai bahan evaluasi.Setelah dilakukan kontainerisasi namun masih terjadi kerusakan dan kehilangan barang maka pihak Direktorat Lalulintas dan Angkutan Laut bersama pihak terkait akan melakukan evaluasi kembali untuk mengambil langkah yang lebih baik.

Untuk mengatasi keterbatasan kondisi pelabuhan Tarempa dilakukan pemerintah daerah melalui upaya menyegerakan realisasi pembangunan dermaga bongkar muat dilokasi baru melalui koordinasi intensifdengan pemerintah pusat. Kedatangan kapal-kapal di pelabuhan Tarempa yang terjadi dalam waktu hampir bersamaan memunculkan permasalahan terkait space dermaga. Hal ini muncul ketika KM. Bukit Raya dan kapal feri penumpang akan sandar, kapal-kapal yang telah sandar sebelumnya akan diminta geser oleh syahbandar untuk memberi kesempatan kapal penumpang sandar terlebih dahulu. Demikian halnya ketika kapal tol laut akan sandar dan kapal penumpang milik PT. PELNI tiba maka kapal tol laut yang belum selesai bongkar muatan pun akan diminta keluar terlebih dahulu, naik turun penumpang lebih diprioritaskan oleh syahbandar.Hal ini juga menjadi penyebab lambatnya proses bongkar muat tol laut.

Dalam jangka pendek ketiadaan gudang penampungan barangdi pelabuhan dapat diatasi dengan palet dan terpal penutup. Langkah ini diambil sebagai upaya menyiasati lambatnya distribusi barang dari dermaga ke konsumen sesuai kebiasaan sistem kerja buruh bongkar muat (TKBM) di Tarempa. Kapasitas transportasi darat di kawasan pelabuhan 
Anwar Sahid, Edy Suandi Hamid, Armaidy Armawi -- Dampak Implementasi Asas Cabotage dan Program Tol Laut Terhadap Ketahanan Wilayah (Studi Di Kabupaten Kepulauan Anambas, Provinsi Kepulauan Riau)

hanya bisa menggunakan kendaraan kecil dengan muatan maksimal $500 \mathrm{~kg}$ sekali jalan. Sistem kerja TKBM juga masih perlu diperbaiki dengan mengacu pola pengaturan buruh pelabuhan yang berlaku nasional atau setidaknya di Provinsi Kepulauan Riau agar kinerjanya lebih baik dan efisien.

Hal penting lainnya adalah sosialisasi prosedur pengiriman barang melalui kapal tol laut dan memfasilitasi pengusaha daerah agar terhubung dengan penyedia barang di Jakarta. Tujuannya agar terbentuk jaringan bisnis antara supplier dan para pelaku usaha baru dari Tarempa. Ke depan diharapkan mereka semakin maju dan menjadi pengguna jasa tol lautsehingga load faktor tol laut akan semakin meningkat.

Selama ini pengusaha Tionghoa mendominasi pasar Tarempa, kehadiran tol laut memberi kesempatan yang sama kepada seluruh pengusaha di Anambas namun sepinya minat justru menjadi peluang pengusahaTionghoa di Tarempa memperoleh margin lebih besar karena selisih biaya angkut kapal tol laut dari kapal swasta lain. Harga eceran barang dilepas sama dengan sebelum ada tol laut sehingga penting dilakukan upaya memperkuat peran BUMD/Perusda agar mampu menjadi penyeimbang harga. Hal ini juga untuk mengantisipasi sentimen negatif masyarakat kepada para pengusaha tersebut yang berpotensi menimbulkan gejolak sosial.

\section{Dampaknya Terhadap Ketahanan Wilayah Di Anambas}

Gatra geografi, kehadiran kapal-kapal nasional di wilayah perairan Kabupaten Kepulauan Anambas sebagai dampak dari implementasi asas cabotage dan tol laut menjadi perekat hubungan antarwilayah kabupaten yang memiliki pulau-pulau dihubungkan oleh laut. Letak geografis Anambas berada di wilayah berbatasan laut langsung dengan beberapa negara tetangga berperan penting dalam menunjukkan eksistensi negara sebagai negara kepulauan terbesar di kawasan Asia Tenggara. Laut tidak bisa dipatok seperti wilayah di darat tetapi bisa dilakukan pengawasan dan penegakkan kedaulatan melalui kehadiran kapal-kapal Indonesia di wilayah tersebut agar menimbulkan efek pencegahan bagi pihak negara lain yang akan melakukan tindakantindakan merugikan Indonesia.

Pemberian kesempatan kepada perusahaan hulu migas menggunakan kapal asing dalam proyek drilling di lepas pantai menurut Syarif, Port Supervisor Jetty Matak erat dengan upaya pencegahan terhadap kejadian fatal yang tidak diinginkan akibat kekeliruan memilih kapal dalam pekerjaan di lepas pantai. Kejadian fatal berupa ledakan di luar kontrol maupun kebakaran akan merugikan perusahaan dan membahayakan lingkungan laut. Hal ini karena potensi wisata bahari Anambas yang eksotis potensial untuk dikembangkan, ditambah dengan posisi geografis kabupaten ini berada jalur pelayaran internasonal memudahkan kapalkapal pesiar untuk singgah dan mengeksplorasi keindahannya.

Kehadiran tol laut memperlancar akses logistik untuk pembangunan Anambas, sehingga upaya mengoptimalkan potensi daerah dalam kaitan letak geografis yang strategis lebih mudah dilakukan. Hal ini berarti bahwa pada gatra geografi Kabupaten Kepulauan Anambas cukup tangguh, tergantung bagaimana pemerintah daerah dan masyarakat menguatkan sisi positif dari keunggulan geografis dengan memanfaatkan momentum hadirnya tol laut dan penguatan cabotage oleh pemerintah pusat. 
Gatra demografi, penduduk yang mendiami wilayah kepulauan seperti Anambas kehidupan sehari-harinya tidak dapat lepas dari laut. Kelahiran dan kematian sebagai bagian alami dalam proses perubahan jumlah penduduk ditambah proses migrasi dalam proses pemenuhan kebutuhan akan mengakibatkan terjadinya perkembangan kependudukan. Perkembangan kependudukan erat dengan pembangunan manusia dinilai melalui indeks pembangunan manusia (IPM) yang menempatkan manusia sebagai tujuan akhir dari proses pembangunan bukan alat produksi. IPM Anambas dari tahun ke tahun meningkat.

Mobilitas penduduk Kabupaten Kepulauan Anambas ke wilayah lain dalam satu provinsi lebih mudah dengan hadirnya kapal tol laut pengangkut penumpang di samping kapal milik PT. PELNI yang telah beroperasi sebelumnya. Hubungan keluarga terjalin baik antarsaudara satu rumpun yang tinggal di pulau berbeda tetap terjaga dengan kehadiran sarana transportasi laut antar pulau yang rutin dan terjadwal.

Meskipun di Anambas masih terdapat masyarakat miskin keberadaan mereka tidak tampak mencolok dalam kehidupan sehari-hari di masyarakat. Hal ini karena meskipun miskin mereka tidak pernah kesulitan mengakses makanan dengan jumlah kalori yang cukup setiap hari sebab laut di sekitar mereka tinggal menyediakannya. Kemudahan-kemudahan mencari nafkah dari laut dan tingkat pendidikan masyarakat yang rendah mendorong perilaku konsumtif. Masyarakat Kota Tarempa khususnya diketahui umum royal dalam pengeluaran, mereka rela membayar mahal untuk memenuhi kebutuhannya. Sebagai contoh ketika harga bensin melambung sampai dengan Rp 30 ribu untuk satu botol ukuran 1,5 liter saat musim cuaca ekstrim yang menyebabkan kapal pengangkut BBM tidak dapat beroperasi, masyarakat tetap rela membelinya asalkan barang tersedia.Hal ini menggambarkan bahwa aspek demografi Anambas pada variabel partisipasi ekonomi dan mobilitas spasial cukup tangguh. Kehadiran tol laut memperlancar akses logistik dan menjamin ketersediaan stok barang kebutuhan masyarakat sehingga penduduk Anambas dapat hidup normal, sehat dan bahagia. Hal ini mendukung peningkatan IPM.

Gatra sumber daya alam, kekayaan alam yangberkontribusi besar terhadap kehidupan masyarakat Anambas di antaranya minyak dan gas bumi, perikanan dan hasil perkebunan. Bertambahnya jumlah kapal yang beroperasi di wilayah perairan Anambas tidak terlepas dari keberadaan industri hulu migas, kehadiran kapal asing maupun kapal nasional mendukung kegiatan eksploitasi maupun distribusi minyak dan gas bumi. Operasional kapal-kapal mendukung pencapaian target produksi yang telah direncanakan pada akhirnya akan memberi manfaat kepada daerah dengan dana bagi hasil yang ditentukan oleh pemerintah pusat. Cabotagedi Anambas diterapkan secara konsisten namun bijaksana melihat realitas bahwa kebutuhan para pengguna jasa kapal terutama proyek pengeboran minyak dan gas bumi belum sepenuhnya mampu dikerjakan oleh kapal-kapal nasional.

Di sisi lain tol laut memberikan opsi pilihan bagi para petani dan pengusaha cengkeh hasil bumi andalan Anambas yang masih bertahan hingga kini. Cengkeh menjadi andalan karena harganya tinggi dan perawatannya tidak rumit. Kehadiran kapal tol laut di Anambas mendorong para pengusaha cengkeh mencari pembeli dengan harga lebih baik di Pulau Jawa. Musim panen yang 
bersamaan menyebabkan para toke (pembeli) lokal membeli dengan harga lebih murah sehingga tol laut menjadi peluang memperoleh harga yang lebih baik di Pulau Jawa melalui angkutan laut yang disubsidi pemerintah.

Gatra ideologi, ketahanan wilayah Anambas pada gatra ideologi diindikasikan oleh adanya kesadaran dan ketaatan yang semakin tinggi dari masyarakat dalam mengamalkan ideologi negara dan peraturan perundangan yang berlaku,hal ini sejalan dengan kecintaan pada tanah air. Kesadaran untuk mematuhi cabotage sesuai peraturan perundangan dan kebijakan pemerintah oleh pihak perusahaan hulu migas di wilayah Anambas menjadi salah satu indikator ketahanan bidang ideologi. Kepatuhan perusahaan hulu migas Medco Energi pada kebijakan pemerintah dalam asas cabotage tercermin dari penurunan jumah kapal asing yang digunakan dalam operasionalnya hingga tahun 2018. Kehadiran negara dalam asas cabotage memperkokoh kecintaan masyarakat Anambas kepada negara.

Kehadiran tol laut bagi masyarakat Anambas meningkatkan rasa cinta tanah air karena kemudahan dalam akses logistik akibat perhatian serius pemerintah pusat. Perhatian pemerintah pusat menggulirkan program tol laut untuk wilayah 3TP meningkatkan rasa cinta tanah air dalam diri masyarakat sejalan dengan rasa syukur warga Anambas atas kehadiran negara dalam menyambungkan wilayah Anambas dengan wilayah lain secara rutin dan terjadwal.

Gatra politik, kehadiran kapal-kapal nasional yang meningkat sebagai dampak dari implementasi cabotage dan tol laut dilihat dari aspek politik penting sebagai bagian menunjukkan kepada dunia keberadaan wilayah NKRI di perairan Laut Cina Selatan yang secara serius diperhatikan oleh negara. Perhatian diwujudkan dengan pembangunan terintegrasi mulai dari wilayah perbatasan dan tol laut hadir mempermudah akses logistik di wilayah ini. Meskipun difokuskan untuk angkutan barang sesuai rute yang ditentukan operator namun dalam kondisi tertentu untuk keperluan pembangunan maka rute yang berdekatan bisa diarahkan sesuai permintaan pemerintah dalam rangka mempercepat proyek-proyek di wilayah 3TP. Misalnya pada akhir tahun 2016 pemerintah membangun Batalyon Komposit di Natuna, kapal tol laut yang semestinya sandar di Tarempa terlebih dahulu diarahkan dulu menuju ke Selat Lampa, Natuna, untuk mengirim peralatan pembangunan proyek tersebut.

Sebagaimana konsep ship promote the trade dampak implementasi tol laut tidak mungkin dicapai dalam waktu singkat karena merupakan sebuah proses yang berkesinambungan dan saling berkaitan antarsektor. Kehadiran tol laut semestinya bisa membawa perubahan kondisi perekonomian di Anambas, dijadikan momentum untuk meningkatkan kemampuan produksi daerah dan meningkatkan kemampuan sumber daya manusia daerah agar mampu berinovasi dan menghasilkan produk-produk unggulan. Jumlah barang muatan dari dan ke Tarempa yang jauh di bawah kapasitas muat kapal tol laut berdampak membebani pemerintah dengan subsidi secara terus menerus karena tingkat keekonomian muatan kapal belum bisa menutupi besar beban operasional kapal.

Gatra ekonomi, secara tidak langsung penerapan asas cabotage memiliki hubungan terhadap perekonomian Kabupaten Kepulauan Anambas, yaitu bahwa penerapan asas ini secara konsisten tanpa memperhatikan kesulitan pihak perusahaan hulu migas di 
wilayah Anambas memperoleh ijin operasional kapal asing yang sangat dibutuhkan justru akan kontraproduktif. Lebih jauh hasil produksi perusahaan yang menurun akan mempengaruhi besaran nilai bagi hasil kepada daerah. Pendapatan asli daerah akan terpengaruh oleh berkurangnya dana bagi hasil migas, hal ini secara tidak langsung akan berdampak pada kehidupan ekonomi masyarakat Anambas.

Keberhasilan proyek pengeboran migas lepas pantai erat ditentukan oleh ketersediaan kapal-kapal sesuai standar dan spesifikasi yang diminta perusahaan. Semestinya perusahaan tidak terhambat beroperasi di perairan Indonesia akibat penerapan ketentuan asas cabotage secara kaku tanpa melihat kemampuan industri pelayaran dalam negeri. Keterlambatan proyek di lokasi ladang migas baru karena menunggu perijinan kapal-kapal asing akibat pengetatan asas cabotage oleh regulator dapat menyebabkan jadwal produksi terganggu. Imbas dari perubahan jadwal produksi bisa mendorong perusahaan melakukan efisiensi untuk menjaga kelangsungan usahanya. Dana bagi hasil migas juga akan terimbas oleh hal itu dan ujungnya pendapatan daerah menurun sehingga pos-pos belanja tertentu akan dipangkas menyesuaikan besaran APBD.

Tol laut secara ekonomi belum dapat memberi dampak terhadap harga barangbarang di pasaran Anambas, meski demikian masyarakat mengakui kehadiran kapal tol laut berhasil menjamin ketersediaan barangbarang di Anambas dan barang tersedia lebih bervariasi. Sebelum kapal tol laut beroperasi ketersediaan barang kebutuhan pokok di pasaran Tarempa pada saat musim angin utara gelombang laut tinggi sering mengalami kelangkaan atau barang-barang 'putus'. Hal ini berdampak pada kenaikan harga yang tidak rasional karena pedagang menjual barang sedang langka di pasar dengan harga tidak wajar. Hadirnya kapal tol laut mampu menjawab persoalan kelangkaan barang-barang tersebut dengan jadwal rutin dan kapasitas muat besar memberi kepastian ketersediaan stok barang pokok dan barang penting sepanjang tahun. Persoalan teknis yang berhubungan dengan operasional lapangan setelah barang tiba di Anambas perlu segera diurai dan diselesaikan bersama para pihak agar tujuan utama program tol laut menurunkan disparitas harga segera tercapai.

Gatra sosial budaya, ketahanan bidang sosial budaya berkenaan dengan persoalan berkisar pada kemampuan masyarakat membina kehidupan yang rukun sejahtera, tetap berkepribadian Indonesia dalam masyarakat majemuk sebagai perwujudan Bhineka Tungal Ika. Pondasi cukup tangguh pada gatra sosial budaya terlihat dari kesadaran akan pentingnya persatuan dan kesatuan bangsa tertanam dalam diri masyarakat Anambas. Hal ini terbukti dengan kondisi kerukunan masyarakat yang tetap terjaga meski multietnis hidup berdampingan selama bertahun-tahun tanpa adanya gejolak sosial. Setiap perayaan hari besar baik keagamaan atau acara tradisi budaya etnis Melayu dan etnis Tionghoa masyarakat Anambas bisa hidup berdampingan saling menghargai dan membantu satu sama lain tanpa menonjolkan perbedaan, menghormati dan menikmati kebersamaan meski berbeda etnis dan agama.

Hubungan sosial antaretnis di Anambas berlangsung baik. Hal ini dapat dilihat juga dari membaurnya masyarakat. Para pedagang besar (supplier) yang didominasi oleh pengusaha keturunan etnis Tionghoa selama ini membaur bersama dengan masyarakat dari etnis lain di 
Anambas dalam rentang waktu lama tanpa ada gesekan berarti. Masing-masing etnis memiliki kekhasan dalam kegiatan ekonomi, masyarakat asli cenderung bertahan menjadi nelayan atau budidaya ikan hidup, masyarakat etnis Tionghoa meneruskan tradisi leluhur yaitu berniaga, sedangkan warga pendatang bekerja mencari nafkah pada sektor-sektor lain sesuai profesinya.

Pengurangan tenaga kerja yang disebabkan oleh perubahan jadwal operasi akibat pengetatan cabotage mengharuskan kapal asing yang bekerja untuk perusahaan hulu migas memperoleh persetujuan dari Menteri Perhubungan untuk dapat beroperasi di wilayah perairan Indonesia akan berdampak kepada masyarakat Anambas yang bergantung hidup kepada perusahaan. Di sisi lain ketersediaan transportasi oleh tol laut yang rutin dan terjadwal menjamin kelangsungan relasi sosial masyarakat Anambas yang dipisahkan pulau dari sanak saudara serumpun. Kapal tol laut dan kapal penumpang lain milik PT. PELNI telah menjadi andalan sekaligus kebanggaan bagi masyarakat di daerah.

Gejolak sosial berpotensi terjadi didorong oleh polarisasi etnis. Para pengusaha Tionghoa dengan basis bisnis kuat di Anambas semestinya memiliki kesadaran mengambil peran dalam mengelola harga-harga secara wajar. Hal ini mengingat para pedagang besar dan distributor barang maupun pengepul ikan hampir seluruhnya etnis Tionghoa. Selama ini masyarakat Anambas memahami perilaku bisnis para pengusaha tersebut dalam mendominasi pasar. Buruh pun bisa mereka pengaruhi untuk mendahulukan barang miliknya saat proses bongkar muatan dari kapal. Harga barang di pasaran bisa mereka pengaruhi dengan kemampuan gudang memadai, modal kuat dan jaringan luas sehingga bisa melebarkan sayap bisnis ke bidang lain. Harga-harga barang di pasaran Tarempa bisa mereka naik-turunkan tanpa ada persaingan. Kemajuan usaha yang tidak diimbangi dengan kesadaran mendukung kebijakan pemerintah dalam hal ini program tol laut akan mempertajam sikap apatis para pengusaha terhadap kondisi lingkungan sekitarnya. Hal ini dapat menambah kecemburuan sosial masyarakat dan menjadi pemicu gejolak sosial yang bisa terjadi sewaktu-waktu.

Gatra pertahanan keamanan, cabotage yang diterapkan di seluruh perairan Indonesia secara nasional telah berhasil meningkatkan jumlah armada angkutan laut berbendera Indonesia. Pertumbuhan signifikan tersebut memperbanyak jumlah kapal nasional yang berlalulintas di wilayah perairan Indonesia, hal ini memberi manfaat terhadap kewaspadaan nasional terhadap setiap kejadian di perairan Indonesia. Setiap armada sipil berbendera Indonesia menurut sudut pandang militer merupakan aset sumber informasi intelejen maritim yang penting. Rutinitas armada niaga nasional di laut menajamkan penguasaan informasi dapat membantu tugas-tugas aparat di laut yang covering area-nya belum dapat mencakup seluruh wilayah perairan Indonesia dalam waktu bersamaan.

Sementara keberadaan keberadaan kapal asing di perairan Indonesia sewaktuwaktu dapat membawa agenda kepentingan negara masing-masing jika negara mereka membutuhkannya. Oleh karena itu sangat penting dominasi armada niaga nasional di wilayah perairan Indonesia agar jika sewaktu-waktu dibutuhkan dapat mendukung kepentingan nasional Indonesia di laut. Potensi armada niaga nasional penting dalam bidang pertahanan dan keamanan, menilik sejarah 
konfrontasi dengan Malaysia sewaktu-waktu bisa dilibatkan dalam perang semesta sesuai keputusan politik pemerintah jika terjadi negara dalam keadaan darurat.

Sukses penerapan asas cabotage akan memperbanyak kehadiran kapal nasional berlayar di wilayah perairan Indonesia, termasuk Anambas sebagai wilayah 3TP bagian dari NKRI. Wilayah yang saat ini menjadi pusat perhatian karena seringnya terjadi tindak pidana perikanan maupun pelanggaran wilayah oleh kapal asing. Kapal perikanan Vietnam, China, Thailand dan Malaysia beberapa kali tertangkap aparat penegak hukum di laut sedang melakukan penangkapan ikan secara ilegal. Mereka menebar jaring ketika aparat sedang tidak patroli di sekitarnya, pada malam hari dengan mematikan lampu untuk mengelabuhi dan menghindari penegak hukum di laut. Kehadiran kapal-kapal nasional yang melintas di area penangkapan tersebut bisa menjadi sumber informasi bagi aparat keamanan di laut melalui saluran komunikasi radio agar segera ditindaklanjuti.

Di sisi lain kehadiran kapal tol laut belum berdampak pada penurunan harga dapat mempertajam sentimen identitas kepada para pengusaha/pedagang etnis Tionghoa karena dianggap hanya mengejar keuntungan besar semata tanpa peduli pada niat baik pemerintah. Masyarakat juga beranggapan kinerja pemerintah daerah cenderung pasif dalam mendukung program ini. Hal demikian berpotensi menurunkan tingkat kepercayaan publik pada kinerja pemerintah daerah. Akumulasi dari sentimen identitas dan ketidakpercayaan masyarakat kepada pemerintah daerah dalam menangani hal itu yang mengerucut berpotensi menimbulkan gangguan keamanan dan ketertiban dalam masyarakat.

\section{SIMPULAN}

Berdasar penjelasan tersebut di atas dapat ditarik simpulan sebagai berikut.

Pertama, implementasi asas cabotage mendorong peningkatan jumlah armada angkutan laut nasional sebesar 356 persen selama kurun waktu 2005-2018. PT. Medco Energi Internasional Tbk di Kabupaten Kepulauan Anambas mematuhi asas cabotage dengan mengurangi pengoperasian kapal asing, kecuali untuk proyek drilling. Selain itu ekspor ikan hidup dari Anamabas masih menggunakan kapal asing. Sedangkan program tol laut ke Anambas telah berjalan baik berhasil menjaga ketersediaan stok dan menambah variasi barang di pasaran.

Kedua, kendala dalam implementasi cabotage, yaitu pencapaian target produksi perusahaan, ketersediaan kapal nasional dan industri pelayaran nasional sulit keluar zona nyaman angkutan laut dalam negeri. Kendala program tol laut trayek ke Anambas pada distribusi barang di lapangan, sehingga target penurunan disparitas harga barang belum tercapai.

Ketiga, kehadiran negara dalam kedua kebijakan tersebut mendorong peningkatan jumlah kapal nasional yang beroperasi di perairan Anambas, mempermudah mobilitas orang dan/atau barang berhasil mendukung pembangunan wilayah. Transportasi dan komunikasi dalam segala bentuk dan pengamanannya itu merupakan wahana kepanjangan kekuasaan dan adminsitrasi pemerintahan serta pembinaan kesatuan dan persatuan bangsa. Kapal-kapal menjadi media penghantar terjadinya interaksi aspek-aspek ketahanan wilayah, dan mendukung ketahanan wilayah. 
Anwar Sahid, Edy Suandi Hamid, Armaidy Armawi -- Dampak Implementasi Asas Cabotage dan Program Tol Laut Terhadap Ketahanan Wilayah (Studi Di Kabupaten Kepulauan Anambas, Provinsi Kepulauan Riau)

\section{DAFTAR PUSTAKA}

Dick, H. W. (1989). Industri Pelayaran Indonesia: Kompetisi dan Regulasi. (Burhanudin \& Maman, Eds.). Jakarta: LP3ES.

Fendos, J., Koo, B., \& Lee, W. (2016). The role of Chinese cabotage in NortheastAsian hub-port development and container shipbuilding. International Journal of Maritime History. https://doi. org/10.1177/0843871416667414

Hamid, E. S. (2004). Implementasi Cabotage Dalam Menunjang Ketahanan Nasional. Jurnal Ketahanan Nasional UGM, IX(2).

Iliopolus, I. (2009). Strategy and Geopolitics of Sea Power throughout History. Baltic Security \& Defence Review, 11(2), 5-218.

Indriyani, R. (2012). Analisis Terhadap Implementasi Azas Cabotage pada Pelayaran di Indonesia dalam Perspektif Kedaulatan Negara Kepulauan. Tesis: Magister Hukum UGM.

Martono, H. K., \& Tjahjono, E. B. (2011). Transportasi di Perairan Berdasarkan UU No 17 Thn 2008. Jakarta: Rajawali Press.

Prihartono, B., \& Dkk. (2015). KONSEP TOL LAUT DAN IMPLEMENTASI 2015 -2019. Jakarta: Bapenas dan Kemenhub RI. Retrieved from http:// www.batukarinfo.com/system/files/ Buku Tol Laut 2015 Lite.pdf

Purwaka, T. H. (1993). Pelayaran Antar Pulau Indonesia Suatu Kajian Tentang Hubungan Antara Kebijaksanaan Pemerintah Dengan Kualitas Pelayanan Pelayaran. Jakarta: Bumi Aksara.

Rumi, D. P. (2017). Implementasi Asas Cabotage Berdasarkan UU No. 17 tahun 2008 tentang Pelayaran terhadap
Industri Angkutan Laut Nasional dan Penerapannya dalam Mendukung Kebijakan Tol Laut. Tesis: Magister Hukum UGM.

Soemarwoto, O. (2014). Analisis Mengenai Dampak Lingkungan (14th ed.). Yogyakarta: Gadjah Mada University Press.

Sunardi, R. M. (1997). Teori Ketahanan Nasional. Jakarta: Hastanas.

Wahyuhono, D., Purwono, S., \& Mutiarin, D. (2019). Kontrol Pemuda Terhadap Tata Kelola Migas Dan Implikasinya Pada Ketahanan Wilayah Di Kawasan Migas Blok Cepu Kabupaten Bojonegoro. Jurnal Ketahanan Nasional, 25(1), 1-14.

\section{Peraturan Perundang-undangan:}

Undang-Undang RI No 17 Tahun 2008 Tentang Pelayaran

Peraturan Presiden Nomor 71 Tahun 2015

Tentang Penyelenggaran Kewajiban Pelayanan Publik untuk Angkutan Barang di Laut.

Peraturan Presiden Nomor 70 Tahun 2017

Tentang Penyelenggaran Kewajiban Pelayanan Publik untuk Angkutan Barang dari dan ke Daerah Tertinggal, Terpencil, Terluar dan Perbatasan. (Pengganti Perpres Nomor 71 Tahun 2015).

Instruksi Presiden RI Nomor 5 Tahun 2005 Tentang Pemberdayaan Industri Pelayaran Nasional.

Peraturan Menteri ESDM Nomor 15 Tahun 2013 Tentang Penggunaan Produk Dalam Negeri pada Kegiatan Hulu Minyak dan Gas Bumi.

Peraturan Menteri Perdagangan Nomor 82 Tahun 2017 Tentang Ketentuan Penggunaan Angkutan Laut dan Asuransi 
Nasional untuk Ekspor dan Impor Barang Tertentu.

Peraturan Menteri Perhubungan Nomor 92 tahun 2018 Tentang Tata Cara dan Persyaratan Pemberian Persetujuan Penggunaan Kapal Asing untuk Kegiatan Lain Yang Tidak Termasuk Kegiatan Mengangkut Penumpang dan/atau Barang dalam Kegiatan Angkutan Laut Dalam Negeri

\section{Data Internet:}

http://anambaskab.go.id/blog/pemkabanambas-buruh-pelabuhan-dan-kapal- tol-laut-bahas-sejumlah-persoalan, diakses 2 November 2018.

http://pidii.info/images/investasi/4th-editions/ kab-kepulauan-anambas/Peta-Anambas. gif, diakses 20 Agustus 2018.

https://batamtoday.com/home/read/120916/ DBH-Migas-Dongkrak-KenaikanAPBD-Anambas-2019, diakses 25 Februari 2019.

\section{Wawancara:}

Wisnu Handoko, Direktur Lalulintas dan Angkutan Laut, Ditjen Hubla.

Syarif, karyawan PT. Medco Energi Tbk./ Port Supervisor Jetty Matak. 